\title{
Beverage consumption in Brazil: results from the first National Dietary Survey
}

\author{
Rosangela A Pereira ${ }^{1, *}$, Amanda M Souza ${ }^{2}$, Kiyah J Duffey ${ }^{3}$, Rosely Sichieri ${ }^{2}$ \\ and Barry M Popkin ${ }^{3}$ \\ 'Department of Social and Applied Nutrition, Universidade Federal do Rio de Janeiro, Av. Carlos Chagas Filho 373, \\ CCS - Bloco J - $2^{\circ}$ andar, Cidade Universitaria, Rio de Janeiro, RJ, Brazil, CEP $21.941-902:{ }^{2}$ Department of \\ Epidemiology, University of the State of Rio de Janeiro, Rio de Janeiro, RJ, Brazil: ${ }^{3}$ Department of Nutrition, University \\ of North Carolina at Chapel Hill, Chapel Hill, NC, USA
}

Submitted 3 September 2013: Final revision received 3 April 2014: Accepted 25 June 2014: First published online 27 August 2014

\begin{abstract}
Objective: To provide an overview of beverage consumption patterns using the first nationally representative survey of dietary intake in Brazil.

Design: Beverage consumption data were obtained by $1 \mathrm{~d}$ food records in an individual dietary survey.

Setting: Nationwide cross-sectional survey, 2008-2009.

Subjects: Nationally representative sample of individuals aged $\geq 10$ years (n 34 003).

Results: Beverages contributed $17 \cdot 1 \%$ of total energy consumption. Caloric coffee beverages provided the greatest level of energy overall $(464 \mathrm{~kJ}(111 \mathrm{kcal}) / \mathrm{d})$. Individuals aged $10-18$ years $(243 \mathrm{~kJ}(58 \mathrm{kcal}) / \mathrm{d})$ and $19-39$ years $(230 \mathrm{~kJ}$ $(55 \mathrm{kcal}) / \mathrm{d})$ consumed a higher proportion of energy from sugar-sweetened soft drinks than individuals over this age $(142 \mathrm{~kJ}(34 \mathrm{kcal}) / \mathrm{d}$ for those aged $40-59$ years and $79 \mathrm{~kJ}(19 \mathrm{kcal}) / \mathrm{d}$ for those aged $\geq 60$ years).

Conclusions: Overall, the contribution of beverages, particularly sugary beverages, to total energy consumption in Brazil represents an important public health challenge and is comparable with those from other countries.
\end{abstract}

\author{
Keywords \\ Dietary survey \\ Energy consumption \\ Sugar-sweetened beverages
}

In the last decades, Brazilians have experienced an unprecedented increase in the prevalence of overweight, obesity and related non-communicable diseases ${ }^{(1,2)}$. In 2008-2009, the prevalence of obesity $\left(\mathrm{BMI} \geq 30 \mathrm{~kg} / \mathrm{m}^{2}\right.$ ) in adults was $12 \%$ in men and $17 \%$ among women. Additionally, since the mid-1970s, the obesity prevalence has increased among teenage boys from 0.4 to $6.0 \%$ and from 0.7 to $4.0 \%$ among teenage girls ${ }^{(1)}$. In $2007,72 \%$ of deaths were attributed to non-communicable diseases, especially stroke, CVD and cancer, with hypertension and diabetes representing major related health problems ${ }^{(3,4)}$.

Declines in physical activity and major changes in overall dietary intake patterns are important contributors to these health outcomes ${ }^{(5-7)}$. A critical component of this change has been a shift away from traditional foods towards a marked increase in the consumption of processed foods ${ }^{(8)}$ and greater away-from-home eating ${ }^{(9)}$. Shifts in overall patterns of beverage consumption have also been found. The growth of the food processing industry in parallel with the expansion of supermarkets has been rapidly diversifying beverage choices in Brazil, particularly sugar-sweetened beverages (SSB), a category that includes not only soft drinks but also milk- and soya-based beverages ${ }^{(6,9-12)}$. The household availability of sodas and milk-based beverages in Brazilian metropolitan areas increased by $500 \%$ between 1974/75 and $2008 / 09^{(13)}$ and the household availability of alcoholic beverages, especially beer, doubled in the same period ${ }^{(14)}$. However, results such as these, based on household expenditure data, likely underestimate overall individual consumption as they exclude away-from-home eating which is an important source of caloric beverages ${ }^{(15,16)}$.

Caloric beverage consumption has become an important source for increases in energy intake around the globe. Since the work of Mattes showing that individuals do not compensate as fully for the intake of energy from liquids ('liquid calories') ${ }^{(17-19)}$, numerous studies and a number of meta-analyses have shown marked effects of SSB intake on increased weight and risk of cardiometabolic outcomes, particularly diabetes ${ }^{(20-24)}$. This is particularly true for studies conducted independent of beverage industry funding ${ }^{(25)}$. SSB consumption has been 
implicated in a large array of other cardiometabolic problems ${ }^{(26-35)}$ and most recently health outcomes like fatty liver disease and visceral fat deposition ${ }^{(36-40)}$.

In addition, SSB consumption is often linked with poorer dietary quality and reduced milk consumption ${ }^{(41-44)}$. A meta-analysis including eighty-eight studies ${ }^{(24)}$ concluded that the available scientific knowledge strongly supports recommendations to reduce soft drink consumption as it is associated with lower intakes of milk and calcium and higher intake of added sugar.

The present study analyses data from the first nationally representative dietary intake survey in Brazil to provide some context for understanding one potentially important factor contributing to the shift in obesity and other cardiometabolic outcomes in Brazil.

\section{Methods}

\section{Study sample}

The present paper analyses data obtained in the first Brazilian Individual Dietary Survey (IDS), carried out by the Brazilian Institute of Geography and Statistics (Instituto Brasileiro de Geografia e Estatística; IBGE) along with the 2008-2009 Brazilian Household Budget Survey (HBS). The IDS examined the food consumption of a representative sample of the Brazilian population aged $\geq 10$ years subsampled from the households investigated in the HBS. The households in the main sample were selected by a two-stage complex cluster sampling design, having the census tracts as primary sampling units and households as secondary sampling units. Prior to the sample selection, homogeneous strata of households were established considering the tracts' location (region, state, rural or urban, capital or other city) and the household heads' income. To reproduce seasonal variations in income, prices and purchase of food and other products, the tracts were equally allocated among the four quarters of the survey (May 2008-May 2009) to guarantee that all strata were represented at all quarters ${ }^{(14)}$. One out of five households selected for the HBS was randomly selected to answer the IDS, assuring that all selected census tracts were represented in the IDS sample ${ }^{(45)}$. The IDS protocol was approved by the Ethics Research Committee from the Institute of Social Medicine, University of the State of Rio de Janeiro.

\section{Beverage data collection}

Data on beverage consumption were obtained by two, non-consecutive, $1 \mathrm{~d}$ food records in which the individuals reported all foods and drinks consumed, the amount consumed, and the time and place of consumption (at home or away from home). Information on water drinking was not collected. A question related to the consumption of sugar and/or artificial sweetener use preceded the food record and the participants were asked which type of sweetener they used more frequently: sugar, artificial sweetener, both or none. Interviewers instructed the participants to complete the food records. Additionally, a booklet was left in the household containing illustrated instructions and examples and including photographs of utensils and containers used to serve food and drinks. The participants were instructed to complete the food records in randomly selected pre-determined days of week following the interviewers' schedule.

The data were first recorded by the participants in an appropriate form and later entered and stored electronically by field interviewers using a computer program specially developed by the IBGE. During the data entry phase, the interviewers reviewed the food records with the participants and probed on usually forgotten foods and periods longer than $3 \mathrm{~h}$ without any reported intake ${ }^{(46)}$ following a previously defined routine.

Interviewers were trained during a 1-week period based on detailed manuals developed to guide the training sessions, which included exercises and practical simulations. Additionally, multimedia material containing examples on the correct way of recording foods and preparations were available for the interviewers. The training and the manuals also covered topics on the input of food consumption data on the computer program. The software comprised a database composed by information obtained on previous HBS including about 1500 pre-coded food items and about 100 units of measurement; however, the interviewers were able to include new food items that were not found in the basic data. Detailed information on the pre-test, interviewers' training process, data collection protocol, evaluation of data quality and validation study are published elsewhere $^{(45)}$.

Portion size measures for the beverages cited in the food diaries were defined from the compilation of previous works on food portioning and proper standardized weighing. When there was the report of units of measurement incompatible with a beverage, which were possibly erroneously recorded (e.g. a piece of coffee), a value was imputed based on the most commonly cited portion size for the specific beverage ${ }^{(45,47)}$. Dilution of fruit in fruit juices, powdered cocoa for chocolate drinks and powdered drink mixes was standardized based on Brazilian research ${ }^{(45)}$.

Nutritional composition of beverages was based on the Brazilian Food Composition Table ${ }^{(48)}$ and on the University of Minnesota Nutrition Coordination Center Nutrient Databank $^{(49)}$. To estimate energy intake, the amount of table sugar added to the beverages (except mate* and flavoured drink mix) was computed using standardization conducted by the $\mathrm{IBGE}^{(45)}$ : if the respondent informed that 'sugar is frequently used in beverages', then $10 \%$ of

\footnotetext{
*. Mate is an infusion prepared from leaves of yerba mate (Ilex paraguariensis) traditionally drunk in the Brazilian South and some states in Central-Western Brazil.
} 
sugarcane was added to the beverage (10 g of sugar for each $100 \mathrm{ml}$ of beverage); if the respondent informed to use both sugar and artificial sweetener, then $5 \%$ of sugarcane was added to the beverage ( $5 \mathrm{~g}$ of sugar for each $100 \mathrm{ml}$ of beverage).

All 171 beverages cited in the food diaries were placed into one of eight groups defined according to the type of beverage, content of energy and addition of sugar or artificial sweetener: (i) caloric/sugar-sweetened coffee beverages (sweetened coffee and cappuccino, sugar-sweetened coffee with milk and teas and infusions); (ii) fruit/vegetable juices (plain and sugar-sweetened fresh squeezed fruit juices); (iii) sugar-sweetened soft drinks (sweetened flavoured drinks, flavoured drinks mix, cola and non-cola sodas, soya beverages, sport drinks, energy drinks); (iv) caloric milk/soyamilk beverages (whole milk, plain soyamilk, milk + fruit-based smoothies, chocolate-flavoured milk, fermented milk, flavoured milk, whey-based beverages); (v) unsweetened low-calorie coffee/tea (plain coffee, unsweetened or artificially sweetened coffee with milk and teas and infusions); (vi) alcoholic beverages (beer, wine, liquors, mixed alcoholic drinks); (vii) low-calorie/low-fat milk/soyamilk beverages (skimmed milk, low-fat milk, diet/light flavoured milk and powdered light soyamilk); and (viii) low-calorie soft drinks (diet/light soda, artificially sweetened flavoured drink mix, light flavoured soya beverages). Meal replacement beverages were excluded from this analysis.

\section{Statistical methods}

Data from the first day of the food record were used to estimate population means of the amount consumed (ml), energy intake ( $\mathrm{kJ}$ or $\mathrm{kcal})$ and percentage of daily energy intake (\%) for each beverage group for four age groups: 10-18 years, 19-39 years, 40-59 years and $\geq 60$ years. Differences in mean intakes across age groups were tested using linear models (GLM) with Bonferroni correction, having the intake of beverages $(\mathrm{ml}, \mathrm{kJ}$ or kcal and \% of total energy intake) as dependent variables, and age group as the independent variable, adjusted by sex and income. Differences in the proportions of demographic and socioeconomic variables across the age groups were tested by the $\chi^{2}$ test for homogeneity.

The odds ratio (and 95\% confidence interval) of consumption of beverage groups according to gender, household income (categorized in quartiles), education ( $\leq 1,2-4,5-8,9-12, \geq 13$ years of schooling), urban or rural location, Brazilian geographic region (North, Northeast, Southeast, South and Central-West) and place of eating (only at home; at least once away from home) were calculated using multivariate logistic regression models, having the consumption of each beverage group (yes/no) as dependent variables and adjusted for age (continuous) and total energy intake. The $\chi^{2}$ test for trend on beverage consumption according to income and education levels was estimated.
Statistical significance was considered with $P<0 \cdot 05$. All analyses were performed using the survey procedures from the SAS statistical software package version 9.3 taking into account the sampling weights and design effect.

\section{Results}

\section{Demographics}

Adolescents (10-18 years) were most likely to be in lowincome households. The proportion of illiterate individuals (defined as those with $\leq 1$ year of schooling) was higher among older individuals, particularly among those $\geq 60$ years old. About $40 \%$ of the overall sample consumed some food away from home, but only $16 \%$ of those $\geq 60$ years old reported away-from-home food consumption (Table 1).

\section{Beverage consumption}

The overall contribution of beverages to total daily energy intake was $17 \cdot 1 \%$, which decreased slightly with age ( $\beta=-0.005 \% ; P<0.01$; data not shown). The beverage groups that contributed most to total daily energy intake in the full sample were the caloric coffee beverages (6.4\%), fruit/vegetable juices (4.7\%) and caloric milk/soyamilk beverages (2.9\%; Table 2 ).

The daily amount of beverages consumed $(\mathrm{ml})$ varied across age groups: individuals aged 19-39 years consumed the highest total amount $(635 \mathrm{ml} / \mathrm{d})$ and elders ( $\geq 60$ years) the lowest $(533 \mathrm{ml} / \mathrm{d} ; P<0 \cdot 01)$. Among adolescents, fruit/vegetable juices contributed to daily energy consumption $(5.2 \%)$ as much as caloric coffee beverages (5.1\%). Adolescents presented the highest (4.1\%) and individuals aged $40-59$ years reported the lowest $(2 \cdot 1 \%)$ contribution of caloric milk/soyamilk beverages to daily energy intake $(P<0 \cdot 01)$. The latter group also presented the highest contribution of alcoholic beverages $(1.0 \%)$ to total daily energy intake $(P<0 \cdot 01)$. Caloric coffee beverages contributed most to daily total energy intake among elders ( $7.7 \%$; Table 2$)$.

\section{Relationship between sociodemographic variables and beverage consumption patterns}

Compared with men, women had a lower probability of drinking alcoholic beverages $(\mathrm{OR}=0 \cdot 4 ; 95 \% \mathrm{CI} 0 \cdot 3,0 \cdot 5)$ but a higher probability of drinking all other beverage groups except caloric coffee beverages and sugar-sweetened soft drinks (for which there was no difference between sexes; Table 3).

The odds of drinking caloric coffee beverages decreased with income $\left(\chi^{2}\right.$ for trend: $\left.P<0.01\right)$ while the odds of drinking sugar-sweetened soft drinks, fruit/vegetable juices and caloric milk/soyamilk beverages increased with income $\left(\chi^{2}\right.$ for trend: $\left.P<0 \cdot 01\right)$. Additionally, compared with all other levels of income, those in the highest quartile of income presented greater odds of consuming 
Table 1 Demographic and socio-economic characteristics and mean energy intake of the sample according to age group: first Brazilian Individual Dietary Survey (IDS), 2008-2009

\begin{tabular}{|c|c|c|c|c|c|}
\hline & $\begin{array}{c}\text { Total } \\
(n 34 \text { 003) (\%) }\end{array}$ & $\begin{array}{l}10-18 \text { years } \\
(n \text { 6939) (\%) }\end{array}$ & $\begin{array}{c}19-39 \text { years } \\
(n 13849)(\%)\end{array}$ & $\begin{array}{l}40-59 \text { years } \\
(n \text { 8893) (\%) }\end{array}$ & $\begin{array}{l}\geq 60 \text { years } \\
(n 4322)(\%)\end{array}$ \\
\hline Total & 100 & 19 & 40 & 27 & 13 \\
\hline \multicolumn{6}{|l|}{ Sex* } \\
\hline Male & 48 & 52 & 49 & 47 & 44 \\
\hline Female & 52 & 48 & 51 & 53 & 56 \\
\hline \multicolumn{6}{|l|}{ Monthly per capita family income $†$} \\
\hline Quartile 1 & 29 & 46 & 31 & 23 & 12 \\
\hline Quartile 2 & 26 & $27^{\mathrm{a}}$ & $27^{a}$ & $25^{\mathrm{a}}$ & $27^{a}$ \\
\hline Quartile 3 & 23 & 17 & $23^{a}$ & $25^{\mathrm{a}}$ & 31 \\
\hline Quartile 4 & 21 & 10 & 20 & $27^{a}$ & $31^{a}$ \\
\hline \multicolumn{6}{|l|}{ Education (years of schooling) $\ddagger$} \\
\hline$\leq 1$ & 11 & 4 & 6 & 14 & 34 \\
\hline $2-4$ & 23 & $29^{a}$ & 12 & $27^{\mathrm{a}}$ & 37 \\
\hline $5-8$ & 27 & 46 & $24^{\mathrm{a}}$ & $24^{a}$ & 12 \\
\hline $9-12$ & 29 & $21^{a}$ & 45 & $23^{\mathrm{a}}$ & 9 \\
\hline$\geq 13$ & 10 & 0.1 & $14^{\mathrm{a}}$ & $13^{\mathrm{a}}$ & 8 \\
\hline \multicolumn{6}{|l|}{ Region } \\
\hline North & 8 & 10 & 8 & 6 & 5 \\
\hline Northeast & 28 & $30^{\mathrm{a}}$ & $29^{a}$ & 24 & 27 \\
\hline Southeast & 43 & 39 & 42 & $46^{\mathrm{a}}$ & $46^{\mathrm{a}}$ \\
\hline South & 15 & $14^{\mathrm{a}}$ & $14^{\mathrm{a}}$ & $16^{\mathrm{b}}$ & $16^{\mathrm{b}}$ \\
\hline Central-West & 7 & $7^{\mathrm{a}}$ & $8^{a}$ & $7^{\mathrm{a}}$ & 6 \\
\hline \multicolumn{6}{|l|}{ Location } \\
\hline Urban & 84 & 80 & $85^{a}$ & $85^{a}$ & 82 \\
\hline Rural & 17 & 20 & $15^{\mathrm{a}}$ & $15^{\mathrm{a}}$ & 18 \\
\hline \multicolumn{6}{|l|}{ Place of eating } \\
\hline At-home only & 60 & $52^{\mathrm{a}}$ & $52^{\mathrm{a}}$ & 65 & 84 \\
\hline At-home and away-from-home & 40 & $48^{\mathrm{a}}$ & $48^{\mathrm{a}}$ & 35 & 16 \\
\hline \multicolumn{6}{|l|}{ Mean energy intake } \\
\hline $\mathrm{kJ} / \mathrm{d}$ & 8037 & 8573 & 8397 & 7703 & 6862 \\
\hline $\mathrm{kcal} / \mathrm{d}$ & 1921 & 2049 & 2007 & 1841 & 1640 \\
\hline
\end{tabular}

a,b Same superscript letters means no differences $(P>0.05)$ between age groups (tested by partitioned $X^{2}$ test).

${ }^{*} X^{2}: P<0.01$ for differences in the proportions of individuals across age groups.

†Monthly per capita family income: total family income divided by the number of family members and categorized into quartiles.

$\ddagger$ The classification of adolescents according to years of schooling is not related to socio-economic category.

unsweetened/low-calorie coffee/tea beverages $(\mathrm{OR}=1 \cdot 6$ $95 \%$ CI $1 \cdot 2,2 \cdot 2)$, low-calorie soft drinks (OR $=5 \cdot 3 ; 95 \%$ CI $2 \cdot 1,12 \cdot 7)$, low-calorie/low-fat milk/soyamilk beverages $(\mathrm{OR}=2.5 ; 95 \% \mathrm{CI} 1.6,4.0)$ and alcoholic beverages (OR $=1 \cdot 8$; $95 \%$ CI 1.1, 3.0; Table 3).

The odds of drinking unsweetened/low-calorie coffee/ tea and alcoholic beverages increased with level of education $\left(\chi^{2}\right.$ for trend: $\left.P<0 \cdot 01\right)$. Additionally, the consumption of low-calorie soft drinks $(\mathrm{OR}=2 \cdot 8 ; 95 \%$ CI 1.1, 7.1) and low-calorie/low-fat milk/soyamilk beverages (OR= $2 \cdot 1 ; 95 \%$ CI $1 \cdot 2,3 \cdot 8$ ) was significantly higher for individuals with $\geq 13$ years of schooling (Table 3 ).

The odds of drinking alcoholic beverages, unsweetened/ low-calorie coffee/tea and low-calorie soft drinks was higher in the Southeast, South and Central-West regions compared with the Northern region, while there was not a significant difference in the probability of drinking alcoholic beverages between the Northeastern and the Northern regions. Moreover, the chance of sugar-sweetened soft drink intake was higher in the Southeastern region. Compared with individuals living in rural areas, the odds of drinking caloric coffee beverages was lower in urban areas $(\mathrm{OR}=0.6$; $95 \%$ CI $0.6,0.7)$ but there were greater odds of drinking sugar-sweetened soft drinks (OR=1.6; $95 \%$ CI 1.4, 1.9), low-calorie soft drinks (OR $=2 \cdot 2 ; 95 \%$ CI $1 \cdot 2,4 \cdot 2)$ and lowcalorie/low-fat milk/soyamilk beverages (OR $=2 \cdot 1 ; 95 \% \mathrm{CI}$ $1 \cdot 3,3 \cdot 4)$ among individuals living in urban areas compared with those from rural areas (Table 3 ).

Individuals reporting away-from-home eating were at increased odds of consuming alcoholic beverages (OR $=$ 2.4; $95 \%$ CI 1.8, 3.2), sugar-sweetened soft drinks (OR= $1 \cdot 8 ; 95 \%$ CI 1.6, 2.0), fruit/vegetable juices (OR $=1 \cdot 3 ; 95 \%$ CI $1.2,1 \cdot 5)$ and low-calorie soft drinks (OR $=1.9 ; 95 \% \mathrm{CI}$ 1.2, 2.9; Table 3).

\section{Discussion}

In Brazil, beverages contributed roughly $17 \%$ to total energy intake and caloric coffee beverages were the most commonly consumed beverage, regardless of age group. Individuals under 40 years old consumed proportionally larger amounts of energy from sugar-sweetened beverages, while individuals aged $40-59$ years old consumed the largest amount of alcoholic beverages. Beverage consumption patterns were differentially associated with gender, income, education and away-from-home eating. Women were less prone to drink alcoholic beverages, but had greater odds of consuming nearly every other type 
of beverage. The consumption of most beverages increased with income, except for caloric coffee beverages, which presented an inverse relationship. Awayfrom-home food consumers presented higher chance of drinking alcoholic beverages, sugar-sweetened soft drinks, fruit/vegetable juices and low-calorie soft drinks.

Data on beverage consumption obtained for the Brazilian population are comparable to those observed for adults in the USA, where energy from beverages represents $18 \%$ of total energy intake ${ }^{(50)}$. Nevertheless, the contribution of beverages to energy intake was lower than the $22.3 \%$ of total energy intake observed in Mexico ${ }^{(51)}$. Estimates for Brazilian adolescents (17.4\% of daily energy intake) are compatible with those for Mexican adolescents $(20 \cdot 1 \% \text { daily energy intake })^{(51)}$ and with results observed for European adolescents, who presented daily energy intake from beverages varying between $11.2 \%$ (Italy) and $20.4 \%$ (Austria) of total energy intake ${ }^{(52)}$. In spite of the role of beverages in the diet, the literature on beverage intake in Brazil is still limited; few studies have observed high consumption of SSB among adolescents ${ }^{(53,54)}$ or the role of beverages in away-from-home eating ${ }^{(15)}$.

SSB have been characterized as a possible important contributor to the epidemic of overweight and obesity, due to their high added sugar content and poor energy compensation $^{(17,18,23,55,56)}$. In another analysis of these same data, we estimated that beverages (excluding alcoholic beverages and milk and milk-based beverages) provided almost half the total sugar in the Brazilian diet $^{(57)}$, which reinforces that beverage consumption is a serious concern for the public health of Brazilians. The rapid growth in SSB and beer sales over the past decade and the increase in purchasing power of most Brazilians only add to concerns about excessive SSB and beer intakes ${ }^{(58)}$.

SSB were introduced recently in the human $\operatorname{diet}^{(43,59)}$; nevertheless, the remarkable expansion of large and small stores for selling processed foods has contributed to rapid shifts in consumption of these products ${ }^{(6,60)}$. In fact, one recent study of processed food estimated that $21 \%$ of all processed food sales in Brazil came from these small corner stores referred to as 'mercadinhos' ${ }^{,(61)}$. While sales of soft drinks, both carbonated and non-carbonated, continue to increase rapidly in Brazil, there is a need to be aware of an array of 'new' products marketed as 'healthy', 'natural' or 'functional' that have also been introduced in Brazil ${ }^{(62,63)}$. Those sugary beverages often incorporate vitamins and minerals, thus eliminating the label of 'empty calorie' foods although they have no proven benefit on human health. Or, as in the USA, they may utilize fruit juice concentrate as their caloric sweetener ${ }^{(64)}$. Additionally, SSB in Brazil use native fruit flavours to be identified as domestic traditional beverages or exotic fruit flavours to enhance their marketing value. Other items known as having beneficial effects have been introduced as 'new' SSB; for example, sugar-sweetened green or white tea. 
Table 3 Odds ratios and $95 \%$ confidence intervals ${ }^{\star}, \dagger$ of beverage consumption according to demographic and socio-economic variables in the Brazilian population aged $\geq 10$ years; first Brazilian Individual Dietary Survey (IDS), 2008-09

\begin{tabular}{|c|c|c|c|c|c|c|c|c|c|c|c|c|c|c|c|c|}
\hline & \multicolumn{2}{|c|}{$\begin{array}{c}\text { Caloric coffee } \\
\text { beverages }\end{array}$} & \multicolumn{2}{|c|}{$\begin{array}{l}\text { Sugar-sweetened } \\
\text { soft drinks§ }\end{array}$} & \multicolumn{2}{|c|}{$\begin{array}{l}\text { Fruit/vegetable } \\
\text { juices\|ll }\end{array}$} & \multicolumn{2}{|c|}{$\begin{array}{l}\text { Caloric milk/ } \\
\text { soyamilk } \\
\text { beverages } \uparrow\end{array}$} & \multicolumn{2}{|c|}{$\begin{array}{l}\text { Unsweetened/low- } \\
\text { calorie coffee/tea** }\end{array}$} & \multicolumn{2}{|c|}{$\begin{array}{l}\text { Low-calorie soft } \\
\text { drinkst† } \\
\end{array}$} & \multicolumn{2}{|c|}{$\begin{array}{c}\text { Low-calorie/low-fat } \\
\text { milk/soyamilk } \\
\text { beverages } \ddagger \ddagger\end{array}$} & \multicolumn{2}{|c|}{$\begin{array}{c}\text { Alcoholic } \\
\text { beverages§§ }\end{array}$} \\
\hline & OR & $95 \% \mathrm{Cl}$ & OR & $95 \% \mathrm{Cl}$ & OR & $95 \% \mathrm{Cl}$ & OR & $95 \% \mathrm{Cl}$ & OR & $95 \% \mathrm{Cl}$ & OR & $95 \% \mathrm{Cl}$ & OR & $95 \% \mathrm{Cl}$ & OR & $95 \% \mathrm{Cl}$ \\
\hline \multicolumn{17}{|l|}{ Sex } \\
\hline Male & 1.0 & - & 1.0 & - & 1.0 & - & $1 \cdot 0$ & - & 1.0 & - & 1.0 & - & 1.0 & - & 1.0 & - \\
\hline Female & 1.0 & $0.9,1.1$ & 1.0 & $1 \cdot 0,1 \cdot 1$ & 1.3 & $1 \cdot 2,1 \cdot 4$ & 1.2 & $1 \cdot 1,1 \cdot 4$ & 1.5 & $1 \cdot 3,1 \cdot 7$ & 1.6 & $1 \cdot 2,2 \cdot 1$ & 1.9 & $1.5,2.4$ & 0.4 & $0.3,0.5$ \\
\hline \multicolumn{17}{|l|}{ Incomel||| } \\
\hline Quartile 1 & 1.0 & - & 1.0 & - & 1.0 & - & 1.0 & - & 1.0 & - & 1.0 & - & 1.0 & - & 1.0 & - \\
\hline Quartile 2 & 0.7 & $0.6,0.8$ & 1.5 & $1.2,1.7$ & $1 \cdot 1$ & $1 \cdot 0,1 \cdot 3$ & 1.4 & $1.2,1.6$ & 1.3 & $1 \cdot 0,1 \cdot 7$ & $2 \cdot 1$ & $1 \cdot 0,4 \cdot 8$ & 1.4 & $0.9,2.2$ & $1 \cdot 1$ & $0.7,1.8$ \\
\hline Quartile 3 & 0.5 & $0.4,0.6$ & 1.6 & $1.3,1.9$ & 1.3 & $1.1,1.5$ & 1.8 & $1.5,2.1$ & 1.2 & $0.9,1.6$ & $2 \cdot 2$ & $0.9,5.4$ & 1.5 & $1 \cdot 0,2 \cdot 3$ & 1.3 & $0.8,2 \cdot 2$ \\
\hline Quartile 4 & 0.4 & $0.3,0.4$ & 1.8 & $1.5,2.2$ & 1.4 & $1.2,1.6$ & 1.9 & $1 \cdot 6,2 \cdot 2$ & 1.6 & $1 \cdot 2,2 \cdot 2$ & $5 \cdot 3$ & $2 \cdot 1,12 \cdot 7$ & 2.5 & $1.6,4.0$ & 1.8 & $1.1,3.0$ \\
\hline \multicolumn{17}{|c|}{ Education (years of schooling)||II } \\
\hline$\leq 1$ & 1.0 & - & 1.0 & - & 1.0 & - & 1.0 & - & 1.0 & - & 1.0 & - & 1.0 & - & 1.0 & - \\
\hline $2-4$ & 1.2 & $1.0,1.4$ & 1.2 & $1 \cdot 0,1 \cdot 4$ & 1.3 & $1.1,1.5$ & 0.9 & $0.8,1 \cdot 1$ & 1.3 & $1 \cdot 0,1 \cdot 7$ & 1.6 & $0.6,4.3$ & 1.0 & $0.6,1.6$ & 1.8 & $1 \cdot 1,2.8$ \\
\hline $5-8$ & 1.3 & $1.1,1.5$ & 1.4 & $1.2,1.6$ & 1.3 & $1.1,1.5$ & 0.9 & $0.7,1.0$ & 1.4 & $1.1,1.9$ & 1.5 & $0.6,3.8$ & 1.3 & $0 \cdot 8,2 \cdot 1$ & $2 \cdot 2$ & $1.4,3.6$ \\
\hline $9-12$ & 1.2 & $1.0,1.5$ & 1.4 & $1.2,1.7$ & 1.7 & $1.5,2.0$ & 0.9 & $0.7,1.0$ & 1.5 & $1.1,2.1$ & 1.6 & $0.7,4.0$ & 1.2 & $0.7,2 \cdot 1$ & 2.6 & $1 \cdot 6,4.3$ \\
\hline$\geq 13$ & 1.0 & $0.8,1.3$ & 1.2 & $1 \cdot 0,1 \cdot 6$ & 1.9 & $1.6,2.4$ & 0.9 & $0.7,1 \cdot 1$ & 2.7 & $1.9,3.9$ & 2.8 & $1 \cdot 1,7 \cdot 1$ & 2.1 & $1.2,3.8$ & $3 \cdot 1$ & $1.8,5.3$ \\
\hline \multicolumn{17}{|l|}{ Region } \\
\hline North & 1.0 & - & 1.0 & - & 1.0 & - & 1.0 & - & 1.0 & - & 1.0 & - & 1.0 & - & 1.0 & - \\
\hline Northeast & 0.8 & $0.7,1.0$ & 1.0 & $0.8,1.1$ & 1.2 & $1 \cdot 0,1 \cdot 3$ & 1.3 & $1.1,1.5$ & 1.3 & $0.9,1.8$ & 0.7 & $0.3,1.3$ & 1.0 & $0.6,1.6$ & 1.4 & $0.9,2 \cdot 1$ \\
\hline Southeast & 0.7 & $0.6,0.8$ & 1.4 & $1.2,1.7$ & 0.8 & $0.6,0.9$ & 1.4 & $1.2,1.7$ & 1.7 & $1 \cdot 1,2.4$ & $2 \cdot 1$ & $1.1,3.9$ & 1.2 & $0.7,1.9$ & $2 \cdot 1$ & $1.4,3.2$ \\
\hline South & 0.8 & $0.7,1.0$ & $1 \cdot 1$ & $1 \cdot 0,1 \cdot 4$ & 0.9 & $0.8,1.1$ & 1.2 & $1 \cdot 0,1 \cdot 4$ & 5.1 & $3.5,7.3$ & 2.6 & $1.3,5.0$ & 1.4 & $0.9,2.4$ & 2.4 & $1.5,3.7$ \\
\hline Central, West & 0.6 & $0.5,0.7$ & 1.0 & $0.8,1.2$ & 1.0 & $0.9,1.2$ & 1.4 & $1.2,1.7$ & 1.7 & $1.1,2.6$ & 2.4 & $1.1,4.8$ & 1.5 & $0.9,2.5$ & 1.9 & $1.2,3.0$ \\
\hline \multicolumn{17}{|l|}{ Location } \\
\hline Rural & 1.0 & - & 1.0 & - & 1.0 & - & 1.0 & - & 1.0 & - & 1.0 & - & 1.0 & - & 1.0 & - \\
\hline Urban & 0.6 & $0.6,0.7$ & 1.6 & $1.4,1.9$ & 1.2 & $1 \cdot 1,1 \cdot 4$ & $1 \cdot 1$ & $1 \cdot 0,1 \cdot 3$ & $1 \cdot 1$ & $0.8,1.5$ & 2.2 & $1 \cdot 2,4 \cdot 2$ & $2 \cdot 1$ & $1 \cdot 3,3 \cdot 4$ & 0.9 & $0.6,1 \cdot 2$ \\
\hline \multicolumn{17}{|l|}{ Place of eating } \\
\hline At home only & 1.0 & - & 1.0 & - & 1.0 & - & 1.0 & - & 1.0 & - & 1.0 & - & 1.0 & - & 1.0 & - \\
\hline At home and away from home & 0.9 & $0.8,1.0$ & 1.8 & $1.6,2.0$ & 1.3 & $1.2,1.5$ & 1.0 & $0.9,1.1$ & 0.9 & $0.7,1.1$ & 1.9 & $1.2,2.9$ & 1.2 & $0.9,1.7$ & 2.4 & $1.8,3.2$ \\
\hline
\end{tabular}

*Significant associations are indicated in bold.

†Multivariate logistic regression models; dependent variables: consumption of each beverage group (no/yes); independent variables: sex, income, education level, eating location, region, urban-rural situation, total energy intake and age (continuous variable)

flncludes sweetened coffee and cappuccino, sugar-sweetened coffee with milk and teas and infusions.

Sncludes sugar-sweetened flavoured drinks, flavoured drinks mix, cola and non-cola sodas, soya beverages, sport drinks, energy drinks.

IIncludes plain and sugar-sweetened fresh squeezed fruit juices.

IIncludes whole milk, plain soyamilk, milk + fruit-based smoothies, chocolate-flavoured milk, fermented milk, flavoured milk, whey-based beverages.

${ }^{* *}$ Includes plain coffee; unsweetened or artificially sweetened coffee with milk and teas and infusions.

t†Includes diet/light soda, artificially sweetened flavoured drink mix, light flavoured soya beverages.

¥łncludes skimmed milk, low-fat milk, diet/light flavoured milk and powdered light soyamilk.

$\S \S$ Includes beer, wine, liquors, mixed alcoholic drinks.

IIII $x^{2}$ for trend: $P<0.01$ for all beverage groups. 
Also, processed beverages containing caffeine and other natural products have been increasing rapidly (e.g. energy drinks with ginseng and guaraná - a high-caffeine Brazilian plant native to the Amazon). Sugar-sweetened and flavoured milk- and soya-based beverages are additional new products that often feature fibre, extra calcium, vitamins, and pre- or probiotics.

As shown in the online supplementary material, Supplemental Fig. 1 - and with more detail in a paper by Kleiman et $a l .{ }^{(12)}$, which showed very rapid growth in energy from beverages sold in Brazil - sugar-sweetened fruit-based and flavoured beverages and energy and sports drinks had remarkable sales increases in the last decade in Brazil, while minimal increases in milk sales were observed. There have been marked increases in beverages sales in Brazil over the last decade and the major increments between 2000 and 2011 were observed for nectars (1219\%), energy drinks (664\% between 2005 and 2011), juice drinks (547\%) and sports drinks (volume: $168 \%)$. On the other hand, drinking milk products had modest increases $(8 \%)$ in per capita volume sales going from $36 \mathrm{~kg} /$ capita per year to $39 \mathrm{~kg} /$ capita per year in the same period. This shift towards these caloric beverages away from milk may at least partially be due to the rising prices of milk products. Additionally, it should be pointed out that $80 \%$ of the fluid milk in Brazil is treated with Ultra High Temperature ${ }^{(65)}$ and marketed in Tetra Pak ${ }^{\circledR}$ packages, which adds cost to the milk. These conditions can help to explain the high prevalence of inadequate calcium consumption, affecting more than $90 \%$ of Brazilian adolescents ${ }^{(45,66-68)}$.

One limitation in the IDS was the measurement of the quantity of sugar added to coffee and selected other beverages, which was standardized based on previous research in Brazil $^{(14)}$, but limits individual variability. Another limitation was the use of the University of Minnesota Nutrient Databank $^{(49)}$ for foods whose composition was not measured in Brazil. Additionally, the present analysis is based only on the first (of two) day of available food records; it is recognized, however, that single $24 \mathrm{~h}$ recalls and food records provide good estimates for population means in extant studies ${ }^{(69)}$. On the other hand, the Brazilian IDS food record was evaluated and provides an accurate estimation of energy intake ${ }^{(70)}$ and the estimates of energy and nutrient intakes were comparable with data obtained in similar studies ${ }^{(71,72)}$. Another limitation is the fact that no data on water consumption were obtained. The role of drinking water consumption on health has been a controversial subject of research ${ }^{(73)}$. Thus, obtaining information about water consumption could be important to assess whether there is a relationship between SSB and water consumption in the Brazilian population.

Caloric beverage intake in Brazil is high and sales trends indicate it is increasing rapidly, particularly for colas and other categories of $\mathrm{SSB}^{(62,74)}$. The results from the present study provide evidence of the importance of beverages to the food and nutrition scenario in Brazil and are important to support the Brazilian dietary guidelines and other initiatives aiming to reduce overweight and obesity-related chronic diseases. Efforts to encourage increased water consumption, reduced use of table sugar in coffee, teas and fruit juices, and decreased consumption of SSB, including by diluting processed juices and nectars with water, should all be supported. Policy research on regulatory and other options to reduce energy intake and improve beverage consumption patterns in Brazil is needed.

\section{Acknowledgements}

Financial support: The Brazilian National Council for Scientific and Technological Development (CNPq - Conselho Nacional de Desenvolvimento Científico e Tecnológico) provided a scholarship to R.A.P. for a sabbatical year in the University of North Carolina at Chapel Hill (CNPq \#200686-2011-9). The CNPq had no had no role in the design, analysis or writing of this article. Conflict of interest: None. Authorship: R.A.P. participated in the study design and conception, data analysis, manuscript conception and writing, and final revision. A.M.S. participated in data analysis and manuscript final revision. K.J.D. participated in the manuscript conception and writing, data analysis, and final revision. R.S. participated in the study design and conception, and manuscript critical revision. B.M.P. participated in the manuscript conception and writing, data analysis, and final revision. All authors have seen and approved the submitted version of the manuscript, take public responsibility for it and provided approval for the publication of this paper. Ethics of human subject participation: The research protocol was approved by the Ethics Research Committee from the Institute of Social Medicine, University of the State of Rio de Janeiro.

\section{Supplementary material}

To view supplementary material for this article, please visit http://dx.doi.org/10.1017/S1368980014001657

\section{References}

1. Instituto Brasileiro de Geografia e Estatística (2010) Pesquisa de Orçamentos Familiares, 2008-2009: Antropometria e Estado Nutricional de Crianças, Adolescentes e Adultos no Brasil. Rio de Janeiro: IBGE.

2. Monteiro CA, D'A Benicio MH, Conde WL et al. (2000) Shifting obesity trends in Brazil. Eur J Clin Nutr 54, 342-346.

3. Ministério da Saúde (2012) Vigitel Brasil 2011: Vigilância de Fatores de Risco e Proteção para Doenças Crônicas por Inquérito Telefônico. Brasília: Ministério da Saúde.

4. Schmidt MI, Duncan BB, Azevedo e Silva G et al. 2011) Chronic non-communicable diseases in Brazil: burden and current challenges. Lancet 377, 1949-1961.

5. Ng SW \& Popkin BM (2012) Time use and physical activity: a shift away from movement across the globe. Obes Rev $\mathbf{1 3}$, 659-680. 
6. Monteiro CA \& Cannon G (2012) The impact of transnational 'Big Food' companies on the South: a view from Brazil. PLoS Med 9, e1001252.

7. Monteiro CA, Gomes FS \& Cannon G (2010) The snack attack. Am J Public Health 100, 975-981.

8. Monteiro CA, Levy RB, Claro RM et al. (2011) Increasing consumption of ultra-processed foods and likely impact on human health: evidence from Brazil. Public Health Nutr 14, 5-13.

9. Bezerra IN \& Sichieri R (2009) Eating out of home and obesity: a Brazilian nationwide survey. Public Health Nutr 12, 2037-2043.

10. Reardon T, Timmer CP, Barrett CB et al. (2003) The rise of supermarkets in Africa, Asia, and Latin America. Am J Agric Econ 85, 1140-1146.

11. Aguiar DRD (2009) The case of Brazil. In Structural Changes in Food Retailing: Six Country Case Studies, pp. 35-39 [KW Stiegert and DH Kim, editors]. Madison, WI: Food System Research Group.

12. Kleiman S, Ng SW \& Popkin B (2012) Drinking to our health: can beverage companies cut calories while maintaining profits? Obes Rev 13, 258-274.

13. Levy-Costa RB, Sichieri R, Pontes Ndos S et al. (2005) Household food availability in Brazil: distribution and trends (1974-2003). Rev Saude Publica 39, 530-540.

14. Instituto Brasileiro de Geografia e Estatística (2010) Pesquisa de Orçamentos Familiares 2008-2009 - Avaliação Nutricional da Disponibilidade Domiciliar de Alimentos no Brasil. Rio de Janeiro: IBGE.

15. Bezerra IN, de Moura Souza A, Pereira RA et al. (2013) Contribution of foods consumed away from home to energy intake in Brazilian urban areas: the 2008-9 Nationwide Dietary Survey. Br J Nutr 109, 1276-1283.

16. Bezerra IN, Souza AeM, Pereira RA et al. (2013) Consumption of foods away from home in Brazil. Rev Saude Publica 47, Suppl. 1, 200S-211S.

17. Mattes RD (1996) Dietary compensation by humans for supplemental energy provided as ethanol or carbohydrate in fluids. Physiol Behav 59, 179-187.

18. DiMeglio DP \& Mattes RD (2000) Liquid versus solid carbohydrate: effects on food intake and body weight. Int J Obes Relat Metab Disord 24, 794-800.

19. Mourao D, Bressan J, Campbell W et al. (2007) Effects of food form on appetite and energy intake in lean and obese young adults. Int J Obes (Lond) 31, 1688-1695.

20. Ebbeling CB, Feldman HA, Chomitz VR et al. (2012) A randomized trial of sugar-sweetened beverages and adolescent body weight. $N$ Engl J Med 367, 1407-1416.

21. de Ruyter JC, Olthof MR, Seidell JC et al. (2012) A trial of sugar-free or sugar-sweetened beverages and body weight in children. $N$ Engl J Med 367, 1397-1406.

22. Malik VS, Popkin BM, Bray GA et al. (2010) Sugar-sweetened beverages and risk of metabolic syndrome and type 2 diabetes: a meta-analysis. Diabetes Care 33, 2477-2483.

23. Malik VS, Schulze MB \& Hu FB (2006) Intake of sugarsweetened beverages and weight gain: a systematic review. Am J Clin Nutr 84, 274-288.

24. Vartanian LR, Schwartz MB \& Brownell KD (2007) Effects of soft drink consumption on nutrition and health: a systematic review and meta-analysis. Am J Public Health 97, 667-675.

25. Lesser LI, Ebbeling CB, Goozner M et al. (2007) Relationship between funding source and conclusion among nutritionrelated scientific articles. PLoS $\operatorname{Med} \mathbf{4}$, e5.

26. Assy N, Nasser G, Kamayse I et al. (2008) Soft drink consumption linked with fatty liver in the absence of traditional risk factors. Can J Gastroenterol 22, 811-816.

27. Bao Y, Stolzenberg-Solomon R, Jiao L et al. (2008) Added sugar and sugar-sweetened foods and beverages and the risk of pancreatic cancer in the National Institutes of Health-AARP Diet and Health Study. Am J Clin Nutr 88, 431-440.
28. Brown IJ, Stamler J, Van Horn L et al. (2011) Sugarsweetened beverage, sugar intake of individuals, and their blood pressure: international study of macro/micronutrients and blood pressure. Hypertension 57, 695-701.

29. de Koning L, Malik VS, Kellogg MD et al. (2012) Sweetened beverage consumption, incident coronary heart disease, and biomarkers of risk in men. Circulation 125 , 1735-1741, S1.

30. Dhingra R, Sullivan L, Jacques PF et al. (2007) Soft drink consumption and risk of developing cardiometabolic risk factors and the metabolic syndrome in middle-aged adults in the community. Circulation 116, 480-488.

31. Fung TT, Malik V, Rexrode KM et al. (2009) Sweetened beverage consumption and risk of coronary heart disease in women. Am J Clin Nutr 89, 1037-1042.

32. Marshall TA, Levy SM, Broffitt B et al. (2003) Dental caries and beverage consumption in young children. Pediatrics 112, e184-e191.

33. Schernhammer ES, Hu FB, Giovannucci E et al. (2005) Sugar-sweetened soft drink consumption and risk of pancreatic cancer in two prospective cohorts. Cancer Epidemiol Biomarkers Prev 14, 2098-2105.

34. Sohn W, Burt BA \& Sowers MR (2006) Carbonated soft drinks and dental caries in the primary dentition. $J$ Dent Res 85, 262-266.

35. Wyshak G (2000) Teenaged girls, carbonated beverage consumption, and bone fractures. Arch Pediatr Adolesc Med 154, 610-613.

36. Stanhope KL (2012) Role of fructose-containing sugars in the epidemics of obesity and metabolic syndrome. Annu Rev Med 63, 329-343.

37. Stanhope KL \& Havel PJ (2010) Fructose consumption: recent results and their potential implications. Ann $N Y$ Acad Sci 1190, 15-24.

38. Song M, Schuschke DA, Zhou Z et al. (2011) High fructose feeding induces copper deficiency in Sprague-Dawley rats: a novel mechanism for obesity related fatty liver. $J$ Hepatol 56, 433-440.

39. Sanchez-Lozada LG, Mu W, Roncal C et al. (2010) Comparison of free fructose and glucose to sucrose in the ability to cause fatty liver. Eur J Nutr 49, 1-9.

40. Abdelmalek MF, Suzuki A, Guy C et al. (2010) Increased fructose consumption is associated with fibrosis severity in patients with nonalcoholic fatty liver disease. Hepatology 51, 1961-1971.

41. Frary CD, Johnson RK \& Wang MQ (2004) Children and adolescents' choices of foods and beverages high in added sugars are associated with intakes of key nutrients and food groups. J Adolesc Health 34, 56-63.

42. Libuda L, Alexy U, Sichert-Hellert W et al. (2008) Pattern of beverage consumption and long-term association with body-weight status in German adolescents - results from the DONALD study. Br J Nutr 99, 1370-1379.

43. Popkin BM (2010) Patterns of beverage use across the lifecycle. Physiol Behav 100, 4-9.

44. Wang YC, Ludwig DS, Sonneville K et al. (2009) Impact of change in sweetened caloric beverage consumption on energy intake among children and adolescents. Arch Pediatr Adolesc Med 163, 336-343.

45. Instituto Brasileiro de Geografia e Estatística (2011) Pesquisa de Orçamentos Familiares, 2008-2009. Análise do Consumo Alimentar Pessoal no Brasil. Rio de Janeiro: IBGE.

46. Sichieri R, Pereira RA, Martins A et al. (2008) Rationale, design, and analysis of combined Brazilian household budget survey and food intake individual data. BMC Public Health 8, 89.

47. Bezerra IN, Monteiro LS, Araujo MC et al. (2012) Procedures for estimating the weight and volume of selected foods reported in cooking units by the National Dietary Survey of 2008. Rev Nutr 25, 646-655. 
48. Núcleo de Estudos e Pesquisas em Alimentação/Universidade de Campinas (2011) Tabela Brasileira de Composição de Alimentos - TACO. Campinas: NEPA/UNICAMP.

49. Nutrition Coordination Center, University of Minnesota (2008) Nutrition Data System for Research - NDSR. Minneapolis, MN: University of Minnesota/NCC.

50. LaComb R, Sebastian R, Enns C et al. (2011) Beverage Choices of US Adults: What We Eat in America, NHANES 2007-2008. Food Surveys Research Group Dietary Data Brief no. 6. Beltsville, MD: USDA/ARS; available at http://ars.usda.gov/Services/docs.htm?docid=19476

51. Barquera S, Hernandez-Barrera L, Tolentino ML et al. (2008) Energy intake from beverages is increasing among Mexican adolescents and adults. $J$ Nutr 138, 2454-2461.

52. Duffey KJ, Huybrechts I, Mouratidou T et al. (2012) Beverage consumption among European adolescents in the HELENA study. Eur J Clin Nutr 66, 244-252.

53. Carmo MBd, Toral N, Silva MVd et al. (2006) Consumption of sweets, soft drinks and sugar-added beverages among adolescents from public schools in Piracicaba, Sao Paulo. Rev Bras Epidemiol 9, 121-130.

54. Sichieri R, Yokoo EM, Pereira RA et al. (2013) Water and sugar-sweetened beverage consumption and changes in BMI among Brazilian fourth graders after 1-year follow-up. Public Health Nutr 16, 73-77.

55. Woodward-Lopez G, Kao J \& Ritchie L (2011) To what extent have sweetened beverages contributed to the obesity epidemic? Public Health Nutr 14, 499-509.

56. Cassady BA, Considine RV \& Mattes RD (2012) Beverage consumption, appetite, and energy intake: what did you expect? Am J Clin Nutr 95, 587-593.

57. Pereira RA, Duffey KJ, Sichieri R et al. (2014) Sources of excessive saturated fat, trans fat and sugar consumption in Brazil: an analysis of the first Brazilian nationwide individual dietary survey. Public Health Nutr 17, 113-121.

58. Ministério da Fazenda (2010) Economia Brasileira em Perspectiva. Brasília: Ministério da Fazenda.

59. Wolf A, Bray GA \& Popkin BM (2008) A short history of beverages and how our body treats them. Obes Rev 9, 151-164.

60. Reardon T \& Berdegué J (2002) The rapid rise of supermarkets in Latin America: challenges and opportunities for development. Dev Policy Rev 20, 371-388.

61. Gómez MI \& Ricketts KD (2013) Food value chain transformations in developing countries: selected hypotheses on nutritional implications. Food Policy 42, 139-150.
62. Euromonitor International (2010) Brazil Soft Drinks Find Growth through Flavour Diversification. London: Euromonitor International.

63. Euromonitor International (2012) Infant Formula in Latin America. London: Euromonitor International.

64. Ng SW, Slining MM \& Popkin BM (2012) Use of caloric and noncaloric sweeteners in US consumer packaged foods, 2005-2009. J Acad Nutr Diet 112, 1828-1834.e1826.

65. Fundação Banco do Brasil (2010) Bovinocultura de Leite. vol. 1: Desenvolvimento Regional Sustentável - Série cadernos de propostas para atuação em cadeias produtivas. Brasília: Fundação Banco do Brasil; available at http:// www.bb.com.br/docs/pub/inst/dwn/Vol1BovinoLeite.pdf

66. Araujo MC, Bezerra IN, Barbosa FS et al. (2013) Macronutrient consumption and inadequate micronutrient intake in adults. Rev Saude Publica 47, Suppl. 1, 177S-189S.

67. da Veiga GV, da Costa RS, Araújo MC et al. (2013) Inadequate nutrient intake in Brazilian adolescents. Rev Saude Publica 47, Suppl. 1, 212S-221S.

68. Fisberg RM, Marchioni DM, de Castro MA et al. (2013) Inadequate nutrient intake among the Brazilian elderly: National Dietary Survey 2008-2009. Rev Saude Publica 47, Suppl. 1, 222S-230S.

69. Dodd KW, Guenther PM, Freedman LS et al. (2006) Statistical methods for estimating usual intake of nutrients and foods: a review of the theory. J Am Diet Assoc 106, 1640-1650.

70. Lopes TS, Ferrioli E, Pfrimer K et al. (2010) Validation of energy intake estimated by the food record applied in a Brazilian national individual dietary survey by the doubly labeled water method. Presented at II World Congress of Public Health Nutrition, Porto, Portugal, 23-25 September 2010.

71. Barquera S, Hernandez-Barrera L, Campos-Nonato I et al.. (2009) Energy and nutrient consumption in adults: analysis of the Mexican National Health and Nutrition Survey 2006. Salud Publica Mex 51, Suppl. 4, S562-S573.

72. Whitton C, Nicholson SK, Roberts C et al. (2011) National Diet and Nutrition Survey: UK food consumption and nutrient intakes from the first year of the rolling programme and comparisons with previous surveys. Br J Nutr 106, 1899-1914.

73. Muckelbauer R, Sarganas G, Grüneis A et al. (2013) Association between water consumption and body weight outcomes: a systematic review. Am J Clin Nutr 98, 282-299.

74. Euromonitor International (2011) Carbonates in Brazil. London: Euromonitor International. 